\title{
Comparative Analysis of Physico-Chemical Parameters of Borehole, Pond and Well Water in Kashere Metropolis
}

\author{
Abdulkadir A. Gidado, Ibrahim Halliru, Christiana A. Kendeson, and Yusuf Abdullahi
}

\begin{abstract}
In a bid to ascertain the quality of water for human consumption in Kashere Metropolis, essential physicochemical parameters were evaluated on samples of drinking water obtained from boreholes, pond and wells located at densely populated areas, labelled as: Kashere cattle market Pond, KP; Kashere cottage Hospital Borehole, HB; Kashere Market Borehole, MB; Federal University, Kashere (FUK) campus Borehole, CB; Kashere cottage Hospital Well, HW; Kashere Market Well, MW and FUK campus Well, CW. Standard procedure for the determination of chemical and physical characteristics of the water samples were used. The results of the investigated parameters in the samples were as follows: $\rho H$ 6.61-7.96, Turbidity 0.0-2568 FTU, Electrical Conductivity 60.5-1151 $\mathrm{Mhocm}^{-1}$, Total Dissolved Solids (TDS) 25.9-518.0 $\mathrm{mgL}^{-1}$, Ca 0.0033-0.5446 ppm, Mg 0.0793-1.2215 ppm, Cd 0.0010-0.0030 ppm, Zn 0.0024-0.1054 ppm, Pb $0.0002-0.0026 \mathrm{ppm}$ and $\mathrm{Fe} 0.0044-0.5649 \mathrm{ppm}$. Except for the concentration of $\mathrm{Fe}$ (in $\mathrm{CB}$; $0.5649 \mathrm{ppm}$ ), all the analyzed minor and major cations in the water samples were in very low concentration and below the permissible limits of WHO standard guidelines values for drinking water. It is recommended that, water from the pond should be properly treated before consumption due to its high turbidity. Also periodic assessment of the quality of drinking water from these water sources should be conducted, to ascertain that they are not contaminated by either or both organic and inorganic pollutants.
\end{abstract}

Index Terms-Drinking Water; Heavy Metals Concentration; Kashere; Physico-chemical; Turbidity.

\section{INTRODUCTION}

People all over the world are dependent on water to grow food, drive turbine to generate power, cool the machines in industries, waste carrier and much more. People use water in their personal lives for bathing and cleaning, recreating, drinking, cooking, gardening and just for the pleasure of watching it. Water also provides habitat for fresh and salt water living organisms. Humans and animals alike obtain their drinking water from surface and ground water sources. However, both surface and ground water sources could become contaminated by biological and chemical pollutants arising from point and non-point sources. More than $97 \%$ of the earth's water is salt water from oceans and salt lakes, while icecaps/glaciers add about $2 \%$ more. Therefore, fresh water is very limited and localized to water in lakes, streams

Published on June 21, 2017

A. A. Gidado is a lecturer at the Department of Chemical Sciences; Federal University Kashere, Nigeria.

I. Halliru is a Senior lecturer at the School of Secondary Education (Science), Department of Chemistry; Federal College of Education (Tech.), Gusau, Zamfara State, Nigeria.

A. C. Kendeson is a lecturer at the Department of Chemical Sciences; Federal University Kashere, Gombe State, Nigeria. (e-mail: kendesonac@yahoo.com)

Y. Aabdullahi is an undergraduate student at the Department of Chemical Sciences, Federal University Kashere, Gombe State, Nigeria. and rivers, which make up less than $0.01 \%$ of the earth's water, and ground water; which make up another 0.6 percent [1].

A little less than a billion of world populations within the developing countries are faced with inadequate availability of potable drinking water [2]. This consequently, resulted to increasing prevalence of water borne diseases caused by organic and inorganic contaminants, in the untreated water usually consumed by that population. Largely, such contaminant is generated by either human activities or borne naturally. In essence, they tend to disrupt the normal function of human or bioorganic system [3]. Metals like mercury $(\mathrm{Hg})$, cadmium $(\mathrm{Cd})$, arsenic $(\mathrm{As})$, chromium $(\mathrm{Cr})$, thallium (Tl), titanium (Ti) and lead $(\mathrm{Pb})$ are among the inorganic contaminants [4]. Their high dosage in human systems lead to serious health problems like membrane rupture and spontaneous abortion, erectile dysfunction, diarrhea, defect in intellectual development of a child, genetic and metabolic disorders, stomach cramps, nausea, vomiting, diarrhea, cancer, liver damage and kidney disease and are even potent carcinogens [5].

Despite the fact that water is a necessity for human existence, and might not be devoid of contaminants, either in safe concentrations or hazardous level; there is no globally recognized standards for quality of drinking water. Those that have been formulated are subject to variations; depending on country, level of economic development and values [6]. The World Health Organization, an arm of the United Nations, provides safely and quality guidelines for drinking water for countries without legislative and administrative frameworks for drinking water quality [5].The government regulatory bodies in Nigeria aimed with the legal right to investigate, regulate, establish and confirm quality of water and other human consumables are the Standard Organization of Nigeria (SON), and National Agency for Food and Drugs Administration and Control (NAFDAC) [4]. The inability or ineffectiveness of those government agencies resulted in alarming rate of production and distribution of unhygienic and unsafe drinking water. However, considering the far-reaching health consequences of deteriorated drinking water quality to our cities and villages in the country, it is important to investigate the quality of these water sources, especially, in regions where potent human activities that give rise to environmental pollutants as effluents are thriving.

Several water quality analyses have been carried out in different parts of the world and many are ongoing in the search for safe, clean and portable drinking water. Leading data have shown variation in physico-chemical parameters of water depending on geographical region, weather conditions and prevailing human activities [7], [8], [9]. Such analytical works were made with the use of sophisticated 
methods including Atomic Absorption Spectrometry (AAS), Inductively Coupled Plasma-Atomic Emission spectroscopy (ICP-AES) and Inductively Coupled Plasma Mass Spectroscopy (ICP-MS).

Most of the analyzed heavy metals in such water were below or within the permissible limit of the world health organization drinking water quality guidelines [6] and the water pollution control regulation of the Turkish authorities [9]. This result is similar to that of Itaogbolu area of Ondo
State, Nigeria [10], although, insignificant impact of the landfill operations on the groundwater resource were observed elsewhere within Nigeria [11].On the other hand, the assessment of fluoride, nitrate and heavy metals in drinking water of North-Eastern India by Singh [12], revealed that concentrations of heavy metals copper, zinc, nickel, cadmium and lead in ground water exceeded the WHO permissible level, with the arsenic concentration been the major threat in Meghalaya.

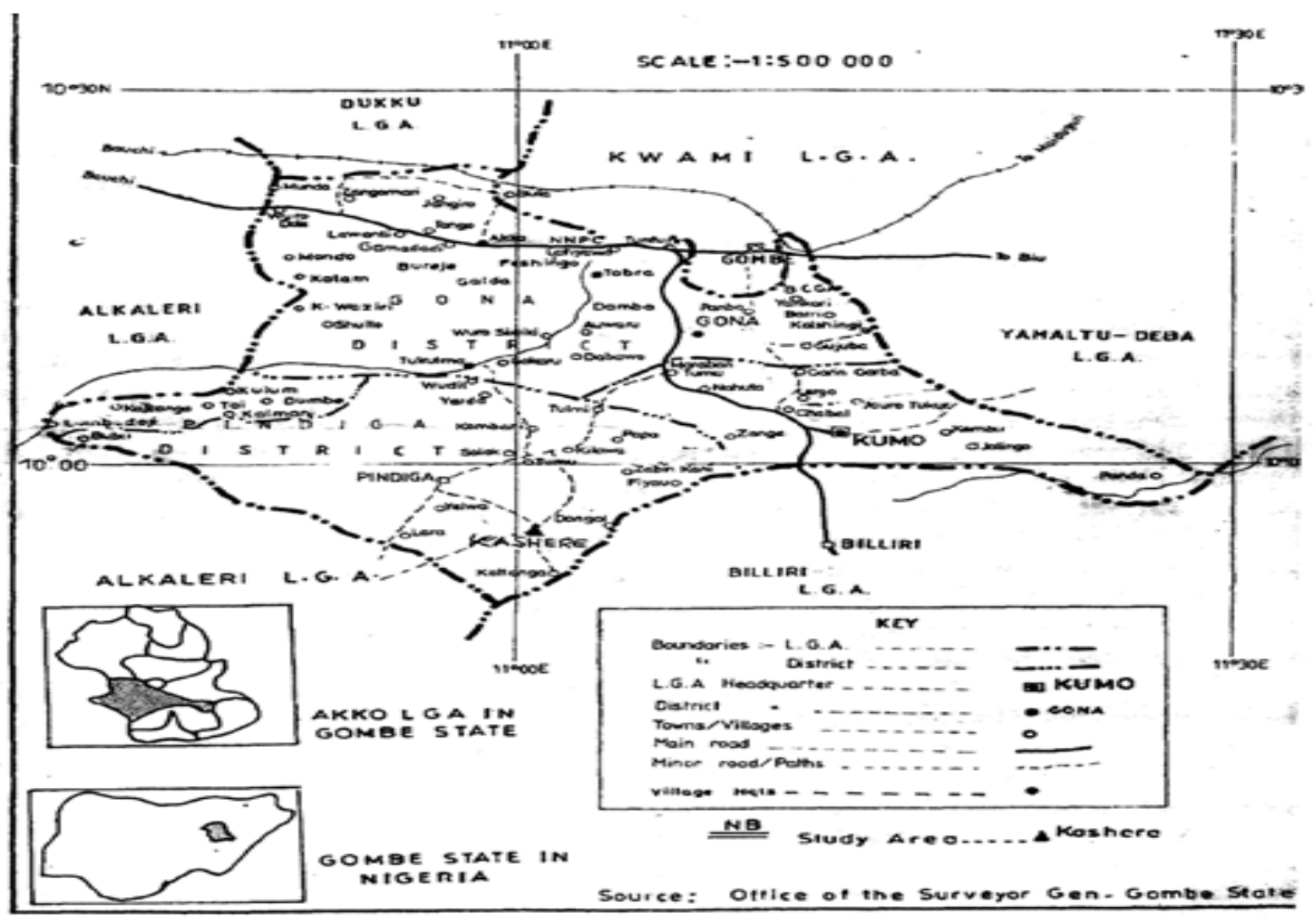

Fig.1. Map of the study area (Akko Local Government Area, Gombe State). Source: Office of the Surveyor General, Gombe State.

In Nigeria, over 170 million people depend on the fresh water in our rivers, lakes, streams and ground water supplies for their drinking water. The study area in this work is Kashere, which is a ward in Akko L.G.A in Gombe State. Scarcity of portable water leads people in this community to consume all sorts of water available even from ponds, which may or may not be fit for drinking. Despite the fact that Kashere is a mining town, where human activities effectively leads to contamination of both underground and surface water; and consequently, effects the growth and development of both plants, animals and human alike, few analytical work were reported as been conducted in the study area. Except for the work of Abdulkadir and coworkers [7], on the assessment of heavy metal contents in two widely used medicinal plants in Kashere, no analytical work have been reported on the physico-chemical composition of borehole, pond and well water around Kashere metropolis. Hence, herein we report the first comparative assessment of metals concentrations ( $\mathrm{Fe}, \mathrm{Pb}$, $\mathrm{Zn}, \mathrm{Cd}, \mathrm{Ca}$, and $\mathrm{Mg}$ ) and analysis of some physico-chemical parameters such as $\mathrm{pH}$, Electrical conductivity (EC), Turbidity, and Total Dissolved Solid (TDS) in several water sources (boreholes, ponds and wells) in Kashere metropolis in Gombe State. The results were objectively compared with WHO standard guidelines for drinking water.

\section{MATERIALS AND METHOD}

All glass ware, mortar, pestle and other surfaces are thoroughly washed and dried in an oven at $120^{\circ} \mathrm{C}$. Analytic balance (JF/JTA JA 5003 series, range: 0-500 g) was used for all weighing and standard mass/weight unit or volume units are used. pH meter (HACH Session), EC-TDS meter (HACH Session 5) and Turbidity meter (HACH DR1890 colorimeter) were used in determining physical parameters: $\mathrm{pH}$, Electrical Conductivity and Turbidity, respectively. Values obtained are recorded in standard units. Water samples were collected in $500 \mathrm{~mL}$ polyethylene containers; initially sterilized prior to use by washing with $20 \%$ analytical grade nitric acid and rigorously rinsed with distilled de-ionized water. They were further rinsed twice with the actual sample at each site before filling. A total of twenty-one (21) samples were collected randomly; three (3) from each site. Duplicate samples were taken for on-site measurement of $\mathrm{pH}$, Total Dissolved Solids (TDS), Electrical Conductivity and Turbidity using a portable meter. The boreholes were allowed to run for at least five 
minutes before the water was collected. Plastic container was used in fetching water from the boreholes, wells and the pond. The collected water samples were acidified with 2.5 $\mathrm{mL}$ of analytical grade nitric acid, well labeled, kept over ice on transit and then refrigerated after arriving at the laboratory at a temperature of $4^{\circ} \mathrm{C}$ prior to analysis.

Analytical grade Nitric acid, Sulphuric acid, Formazin solution, Hydrogen Peroxide and all other chemicals used were of analytical grade purchased from Sigma-Aldrich or Fluka and used as obtained. Freshly prepared doubled distilled water was used in all experiments. Atomic absorption measurements were made using VARIAN AA24OFS Fast Sequential Atomic Absorption Spectrometer (Ahmadu Bello University, Zaria), and digestion conducted using Milestone Acid digestion method. All filtrations were done in triplicate with Whatman No. 41 filter paper. Stock standard solutions of $\mathrm{Fe}, \mathrm{Pb}, \mathrm{Cd}$, and $\mathrm{Zn}$ metal ions were made. $\mathrm{Ca}$ and $\mathrm{Mg}$ were determined directly using the flame atomic absorption spectrometer. Calibration standards of each target metal ion were obtained by appropriate dilution of the stock solution. Suitable hollow cathode lamps for analyzed metals were used as reference sources. Under optimum operating conditions, the metals were measured using an air-acetylene flame. The absorbance of each metal in the sample solution was obtained and the calibration curve prepared to obtain the concentration. The concentration of each metal was calculated using the formula below:

Final Concentration $(\mathrm{mg} / \mathrm{L})=$ concentration of metal $x$ dilution factors $x$ nominal volume/sample volume $(\mathrm{mL})$.

The data obtained from chemical analysis were subjected to descriptive statistical analysis (mean, range and standard deviation at $95 \%$ confident limit).

\section{A. Measurement of $p H$}

The $\mathrm{pH}$ of the water samples were measured at the time of collection by using portable battery operated $\mathrm{pH}$ meter. The calibration was done with standard buffer solution, and reading taken after the indicated value remains constant for about one minute. After each measurement, the electrode of the $\mathrm{pH}$ meter was washed with distilled water and cleaned with tissue paper before reuse.

\section{B. Total Dissolved Solids (TDS)}

This refers to organic solid matter dissolved in water or sewage. Solids may affect water or effluent quality adversely in a number of ways. Waters with high dissolved solids generally are of inferior palatability and may have an unfavourable physiological reaction in the transient consumer. For this reason there is a limit of $500 \mathrm{mg} / \mathrm{L}$ for some organic substances and dissolved gases. The Total Dissolved Solids (TDS) of the samples were measured using pre-calibrated E.C-TDS meter. The samples were transferred into beaker in specific volume to dip the electrode, after which the button was pressed and the scale was set before the TDS of each sample was noted. Prior to measurement, the beaker and the electrode must be washed several times with the solution under test and the measurement taken at room temperature.

\section{Electrical Conductivity}

Electrical conductivity is the measure of water ability to convey electricity. The conductivity of the samples was measured using pre-calibrated conductivity meter. Before the measurement, the beaker and the electrode were washed several times with the solution under test and the measurement was taken at room temperature. The samples were transferred into beaker in enough volume to dip the electrode. After which the button was pressed and the scale was set before the conductivity of each sample was then noted.

\section{Turbidity Determination}

Turbidity is the measure of water clarity and transparency. That is the cloudiness or haziness of water caused by large numbers of individual particles that are generally invisible to the naked eye. To determine the turbidity of the samples, turbidity meter was used after calibration with formazin primary standard.

\section{E. Digestion of the Water Samples}

The digestion was done using the Milestone Acid digestion method. One milliliter $(1 \mathrm{~mL})$ of each water sample was pipette into $20 \mathrm{mLTeflon}$ tube. Concentrated nitric acid (6.5 mL, $65 \%$ Assay), hydrochloric acid (2.5 mL, $37 \%$ Assay) and hydrogen peroxide $(0.25 \mathrm{~mL})$ were added to each sample. A blank was prepared using $\mathrm{HNO}_{3}(6.5$ $\mathrm{mL}), \mathrm{HC} 1(2.5 \mathrm{~mL})$ and $\mathrm{H}_{2} \mathrm{O}_{2}(0.25 \mathrm{~mL})$. The samples were then placed in an ETHOS 900 microwave digester for thirty minutes. After digestion, the samples were allowed to cool to room temperature and the solutions then diluted to with distilled de-ionized water $(20 \mathrm{~mL})$. The liquid extract obtained was then used for the determination of Iron, Lead, Cadmium and Zinc using VARIAN AA24OFS Fast Sequential Atomic Absorption Spectrometer. Calcium and Magnesium were determined directly using the flame atomic absorption spectrometer.

\section{RESULTS AND DISCUSSION}

\section{A. Samples and Sampling}

A total of four (4) locations for drinking water samples in Kashere metropolis were selected, based on the fact that they are areas prone to most human activities that might likely leads to contamination of both underground and surface water in Kashere. They were Federal University, Kashere (FUK) Campus area, Kashere Market area, Kashere Cottage Hospital and a Pond near Kashere Cattle Market (Table I). The water sources include Boreholes, Pond and Wells.

TABLE I: SAMPLING SITES AND SAMPLE I.D

\begin{tabular}{llc}
\hline \hline S/N & Sampling site & Sampling I.D \\
\hline 1 & FUK Campus Borehole & CB \\
2 & FUK Campus Well & CB \\
3 & Kashere Market Borehole & MB \\
4 & Kashere Market Well & MW \\
5 & Kashere Cottage Hospital Borehole & HB \\
6 & Kashere Cottage Hospital Well & HW \\
7 & Kashere Cattle Market Pond & KP \\
\hline \hline
\end{tabular}


Twenty-one (21) water samples were collected randomly; three (3) from each of the seven sampling sites in the month of July, 2015. Duplicate samples were taken for on-site measurement of $\mathrm{pH}$, Total Dissolved Solids (TDS), Electrical Conductivity and Turbidity using a portable meter. The boreholes were allowed to run for a while before the water was collected. Plastic containers were used in collecting the samples. The collected water samples were acidified with $2.5 \mathrm{~mL}$ of analytical grade nitric acid, well labeled, kept over ice on transit and then refrigerated prior to analysis.

\section{B. Analysis of Physico-Chemical Parameters}

The parameters for water quality are determined by the intended use i.e. for human consumption, industrial use or in the environment [13]. The physico-chemical quality of the drinking water varied drastically among the different sites of Kashere metropolis. Results obtained on the different parameters in the drinking water samples were referred to the WHO (2004) guidelines for correlation. Table II, illustrates the result of physical parameters (pH, E.C, TDS and turbidity), while the mean concentration standard deviation $(\mathrm{ppm} \pm \sigma)$ of the chemical parameters in the water samples were given in Table III. All analyses were done in triplicate, and averages of the results are presented.

TABLE II: THE RESUltS OF PHYSICAL PARAMETERS OF WATER SAMPLES AS COMPARED WITH WHO (2004), STANDARD GUIDELINES FOR

\begin{tabular}{llcccc}
\multicolumn{7}{c}{ DRINKING WATER } \\
\hline \hline S/N & $\begin{array}{l}\text { Sampling } \\
\text { I.D }\end{array}$ & $\mathrm{P}^{\mathrm{H}}$ & $\begin{array}{c}\text { Turbidity } \\
(\text { FTU) }\end{array}$ & $\begin{array}{c}\text { EC(Mhocm } \\
-1)\end{array}$ & $\begin{array}{c}\text { TDS } \\
\left(\mathrm{mgL}^{-1}\right)\end{array}$ \\
\hline 1 & KP & 6.61 & 2568.0 & 60.5 & 25.9 \\
2 & CW & 7.02 & 71.0 & 123.3 & 53.6 \\
3 & MW & 7.30 & 30.0 & 1151.0 & 518.0 \\
4 & HW & 7.96 & $*$ & 1096.0 & 493.0 \\
5 & CB & 7.52 & 34.0 & 136.3 & 59.2 \\
6 & MB & 7.19 & $*$ & 159.8 & 69.6 \\
7 & HB & 7.93 & 23.0 & 402.0 & 177.2 \\
8 & WHO & $6.5-$ & 5 & 1000 & 500 \\
& standard & 8.5 & & & \\
\hline \hline & guidelines & $*$ Below detection limit & &
\end{tabular}

TABLE III: MEAN CONCENTRATION STANDARD DEVIATION $(\mathrm{PPM} \pm \Sigma)$ OF THE CHEMICAL PARAMETERS IN THE WATER SAMPLES AS COMPARED WITH WHO (2004), DRINKING WATER QUALITY STANDARDS/GUIDELINES IN

\begin{tabular}{cccccccc}
\multicolumn{7}{c}{ PPM FOR CHEMICAL PARAMETERS } \\
\hline \hline S & Sampl & Cd & $\mathrm{Zn}$ & $\mathrm{Pb}$ & $\mathrm{Fe}$ & $\mathrm{Ca}$ & $\mathrm{Mg}$ \\
$\mathrm{N}$ & ing & & & & & & \\
\hline 1 & K.D & & & & & & \\
& & 0.001 & 0.010 & 0.000 & 0.166 & 0.003 & 0.159 \\
& & $8 \pm 0.0$ & $8 \pm 0.0$ & $9 \pm 0.0$ & $8 \pm 0.0$ & $3 \pm 0.0$ & $0 \pm 0.0$ \\
2 & $\mathbf{C W}$ & 0.001 & 0.011 & 0.000 & 0.049 & 0.009 & 0.079 \\
& & $3 \pm 0.0$ & $8 \pm 0.0$ & $7 \pm 0.0$ & $5 \pm 0.0$ & $5 \pm 0.0$ & $3 \pm 0.0$ \\
& & 005 & 003 & 002 & 049 & 005 & 018 \\
3 & $\mathbf{M W}$ & 0.00 & 0.024 & 0.000 & 0.023 & 0.208 & 0.422 \\
& & $10 \pm 0$. & $3 \pm 0.0$ & $2 \pm 0.0$ & $3 \pm 0.0$ & $7 \pm 0.0$ & $6 \pm 0.0$ \\
& & 0005 & 028 & 006 & 055 & 014 & 021 \\
4 & $\mathbf{H W}$ & 0.001 & 0.002 & 0.000 & 0.014 & 0.544 & 0.789 \\
& & $3 \pm 0.0$ & $5 \pm 0.0$ & $6 \pm 0.0$ & $1 \pm 0.0$ & $6 \pm 0.0$ & $5 \pm 0.0$ \\
& & 004 & 004 & 002 & 035 & 025 & 009 \\
5 & $\mathbf{C B}$ & 0.001 & 0.016 & 0.001 & 0.564 & 0.028 & 0.178 \\
& & $1 \pm 0.0$ & $4 \pm 0.0$ & $1 \pm 0.0$ & $9 \pm 0.0$ & $7 \pm 0.0$ & $5 \pm 0.0$ \\
& & 002 & 009 & 005 & 038 & 002 & 016 \\
6 & MB & 0.003 & 0.002 & 0.002 & 0.004 & 0.030 & 1.22 \\
& & $0 \pm 0.0$ & $4 \pm 0.0$ & $6 \pm 0.0$ & $4 \pm 0.0$ & $6 \pm 0.0$ & $15 \pm 0$. \\
& & 009 & 022 & 007 & 006 & 005 & 0000
\end{tabular}

\begin{tabular}{cccccccc}
7 & HB & 0.001 & 0.105 & 0.000 & 0.171 & 0.047 & 0.422 \\
& & $4 \pm 0.0$ & $4 \pm 0.0$ & $5 \pm 0.0$ & $7 \pm 0.0$ & $0 \pm 0.0$ & $6 \pm 0.0$ \\
8 & & 002 & 003 & 001 & 009 & 005 & 021 \\
& WHO & $0.01-$ & $5-15$ & $0.05-$ & $0.3-$ & 200 & 150 \\
& standa & No & & No & 1.0 & & \\
rd & relaxa & & relaxa \\
guidel & tion & & tion & & \\
ines & & & & & \\
& & & & & \\
\hline \hline
\end{tabular}

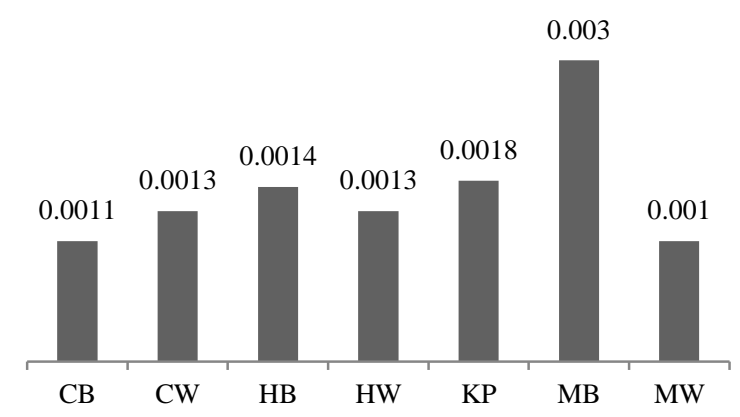

Fig 2. Mean concentration of Cd in water samples (ppm)

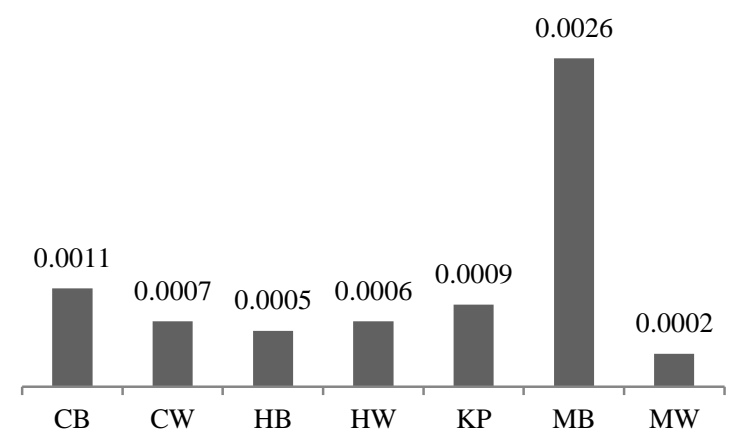

Fig. 3. Mean concentration of $\mathrm{Pb}$ in water samples (ppm)

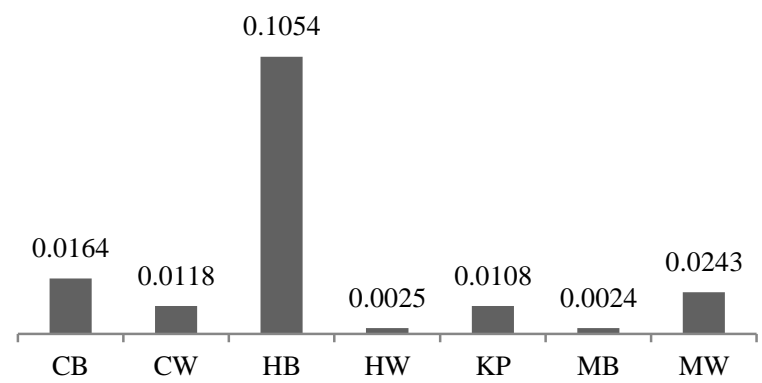

Fig. 4. Mean concentration of $\mathrm{Zn}$ in water samples (ppm)

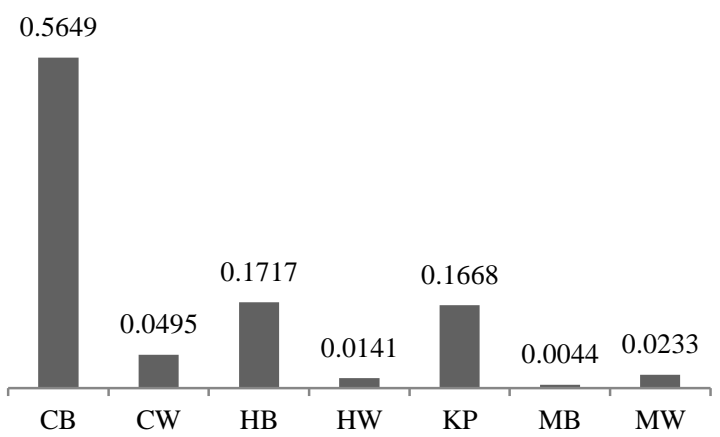

Fig. 5. Mean concentration of Fe in water samples (ppm) 


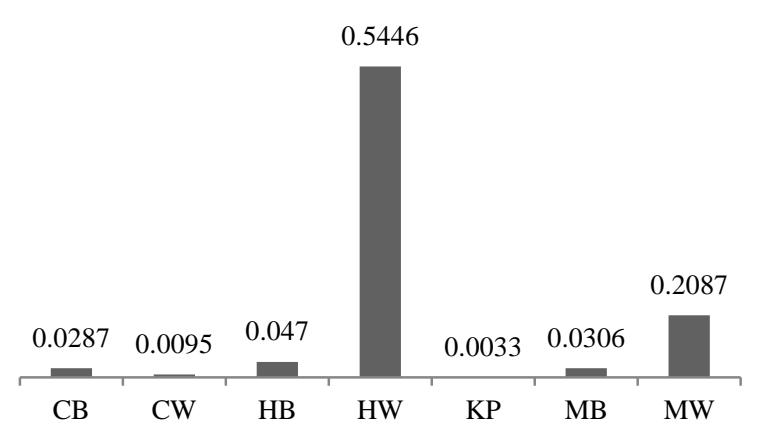

Fig. 6. Mean concentration of $\mathrm{Ca}$ in water samples (ppm)

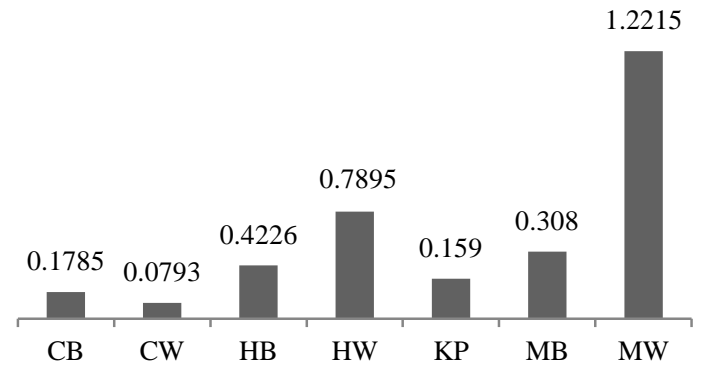

Fig. 7. Mean concentration of $\mathrm{Mg}$ in the water samples (ppm)

The $\mathrm{pH}$ of all water samples collected from wells was found to range from 7.02 to 7.96 with a mean value of 7.43 (Table II). CW and HW recorded both the minimum (7.02) and maximum (7.96) $\mathrm{pH}$ values for the water samples respectively. In the same vein, the $\mathrm{pH}$ values of boreholes water samples fall within the range 7.19-7.93 with a mean value of 7.55. The lowest $\mathrm{pH}$ value of 7.19 was recorded in $\mathrm{MB}$ and the highest $\mathrm{pH}$ value of 7.93 recorded in $\mathrm{HB}$ water sample. The $\mathrm{pH}$ of water sample from KP was 6.61. The WHO specified $\mathrm{pH}$ value range for drinking water is 6.5-8.5. Interestingly, it was observed that all the $\mathrm{pH}$ values of the water samples analyzed are within the WHO permissible limits and therefore fit for drinking in terms of their $\mathrm{pH}$ values.

The turbidity values of drinking water samples collected from wells were found to range from 0.0 FTU to71.0 FTU with a mean turbidity value of 33.7 FTU. The lowest turbidity of 0.0 FTU was observed in HW while, the highest turbidity of 71.0 was observed in $\mathrm{CW}$. The turbidity values of borehole water samples were found to range 0.0-34. OFTU; with a mean turbidity value of 19.0 FTU. Lowest turbidity value of 0.0 FTU was observed in $\mathrm{MB}$ and the highest turbidity of 34.0 FTU was seen in CB water sample. Highest turbidity value of 2568.0 FTU was recorded for KP. WHO establishes that the turbidity of drinking water should not be more than 5.0 NTU or FTU and should ideally be <1.0 NTU. In this study, two water samples (Table 2; Turbidity: entry 4 and 6) were below the permissible limit of WHO [6], while the remaining five were found to be above the recommended limits. The higher the turbidity level in drinking water, the higher the risk of people developing gastrointestinal diseases such as diarrhea, vomiting and abdominal cramps etc. This is because contaminants like viruses or bacteria can become attached to the suspended solid particles. The highest turbidity value recorded was in water sample collected from Kashere pond, KP (2568.OFTU) and this might be due to its nature as surface drinking water source which is prone to contamination by both human and animal activities.

The Electrical Conductivity, EC, values of drinking water samples collected from wells were found to range from 123.3 to $1151.0 \mathrm{Mhocm}^{-1}$ with a mean value of 790.1 $\mathrm{Mhocm}^{-1}$. CW has the lowest EC values of $123.3 \mathrm{Mhocm}^{-1}$ and MW has the highest EC value of $1151.0 \mathrm{Mhocm}^{-1}$. The EC values of water samples collected from boreholes were within the range of 136.3-402.0 $\mathrm{Mhocm}^{-1}$ with average value of 232.7 Mhocm $^{-1}$. CB and HB gave the lowest (136.3 $\left.\mathrm{Mhocm}^{-1}\right)$ and highest $\left(402.0 \mathrm{Mhocm}^{-1}\right)$ values for electrical conductivity in the samples of borehole water. In this same vein, $\mathrm{KP}$, gave the least $\left(60.5 \mathrm{Mhocm}^{-1}\right) \mathrm{EC}$ value in all the samples of water analyzed. The WHO recommended EC value for drinking water is $1000 \mathrm{Mhocm}^{-1}$ [6]. In this study, the results (Table 2) showed that two water samples; MW and HW, were above the WHO permissible limits. Higher conductivity may be attributed to high salinity and high mineral percentage in the groundwater samples, which are generally due to the ion exchange and solubilization process taking place in the aquifers.

The Total Dissolved Solids, TDS values of water samples collected from wells were found to range between 53.6 to $518.0 \mathrm{mg} / \mathrm{L}$ with a mean TDS value of $354.9 \mathrm{mg} / \mathrm{L}$. The lowest TDS of $53.6 \mathrm{mg} / \mathrm{L}$ was observed in $\mathrm{CW}$, while the highest in the well water samples of $518.0 \mathrm{mg} / \mathrm{L}$ recorded in MW. The TDS values of water samples collected from boreholes were in the range $59.2 \mathrm{mg} / \mathrm{L}-177.2 \mathrm{mg} / \mathrm{L}$ with a mean TDS of $102 \mathrm{mg} / \mathrm{L}$. High TDS of $177.2 \mathrm{mg} / \mathrm{L}$ was found in $\mathrm{HB}$ and low TDS of $59.2 \mathrm{mg} / \mathrm{l}$ found in CB. The TDS value for KP was found to be $25.9 \mathrm{mg} / 1$. In this study, only one MW was found to be above the WHO permissible limit of $500 \mathrm{mg} / \mathrm{L}$. Dissolved Solids are the most important water pollutants because they play a major role in the transmission of pathogens. High concentration of TDS in drinking water may be due to entrance of waste water and effluents into the water source through improper dumping of domestic and municipal solid waste and leaching of chemicals and sewage or weathering of rocks and soil.

The lowest and the highest levels of heavy metals detected ranged between $0.0002 \mathrm{ppm}$ for $\mathrm{Pb}$ and $0.5649 \mathrm{ppm}$ for Fe (Table III). Cadmium concentrations in the drinking water samples were in the range of $0.0010-0.0030 \mathrm{ppm}$; with the lowest and the highest values recorded in MW and MB respectively. The concentration of cadmium allowed in drinking water by World Health Organization (WHO) is $0.010 \mathrm{ppm}$. Consequently, no contamination due to cadmium can be said to exist in the water samples (Table III and Fig. 2).

The highest Fe concentration was found in $\mathrm{CB}$ as 0.5649 $\mathrm{ppm}$ and the lowest in $\mathrm{MB}$ as $0.0044 \mathrm{ppm}$. WHO recommended value of $\mathrm{Fe}$ concentration in drinking water is 0.3000-1.0000 ppm. Therefore, $\mathrm{Fe}$ is within the recommended range of WHO standard guidelines. The levels of $\mathrm{Pb}$ in the samples were in the range of 0.0002-0.0026 ppm with lowest and highest values recorded in MW and MB respectively (Table III and Fig. 3, 4). The action level for $\mathrm{Pb}$ as recommended by WHO in drinking water is $0.05 \mathrm{ppm}$, and fortunately, concentration of $\mathrm{Pb}$ in all the water samples were below this level. A major source of environmental $\mathrm{Pb}$, particularly in urban areas, is due to the 
combustion of leaded gasoline. $\mathrm{Pb}$ is discharged by vehicles into air, and then adsorbed from the air by environmental samples such as soil and plants [9]. It then leached into the waterways from soil, thus affecting the levels of the metal in natural waters.

The concentration of zinc in the water samples were in the range of $0.0024-0.1054 \mathrm{ppm}$; with the lowest and the highest values recorded for MB and HB respectively (Table III and Fig. 4). Both $\mathrm{Zn}$ and Fe are considered as essential elements to the human body with the recommended level of $\mathrm{Zn}$ in drinking water by WHO being 5-15 ppm. However, $\mathrm{Zn}$, was found to be below this level in all the water samples investigated. Calcium and Magnesium in the investigated water samples were found in the range of 0.0033-0.5446 ppm and 0.0793-1.2215 ppm, respectively (Table III and Fig.6,7.). $\mathrm{Ca}^{2+}$ and $\mathrm{Mg}^{2+}$ ions are important for total hardness of water. The concentration of both ions in the drinking water samples were below the WHO standards.

\section{CONCLUSION}

The study analyzed some physico-chemical parameters of drinking water from boreholes, a pond and wells from Kashere metropolis. A total of seven water samples (CB, $\mathrm{CW}, \mathrm{HB}, \mathrm{HW}, \mathrm{KP}, \mathrm{MB}$ and $\mathrm{MW}$ ) were collected from the four sampling sites (FUK campus area, Kashere Cottage hospital, Kashere market square and a pond near Kashere Cattle market). Standard procedures for the determination of physical and chemical parameters of the water samples were employed. Concentrations of $\mathrm{Fe}, \mathrm{Pb}, \mathrm{Cd}, \mathrm{Zn}, \mathrm{Ca}$ and $\mathrm{Mg}$ in the samples were determined using Atomic Absorption Spectrometer. Results obtained indicates that major and minor ions are present in very small concentrations in all the water samples and heavy metals concentrations followed the order $\mathrm{Fe}>\mathrm{Zn}>\mathrm{Cd}>\mathrm{Pb}$. Some of the physical parameters were above the [6] permissible limit, but most of these parameters were within the acceptable limit.

Consequently, drinking water from Kashere metropolis is fit for consumption in terms of heavy metals concentration even though; few of the physical parameters exceeded the World Health Organization guideline values. The data clearly indicated that the ground water quality is affected by local physiographic structure and possibly ground water flow.As this present assessment is limited to Kashere metropolis due to time and financial constraint, results gathered might not be entire sufficient for policy implementation for the whole state. It is therefore suggested that modern water treatment processes should be employed in bringing the level of exceeded physical and chemical parameters to the acceptable limit. This will foster the production of potable drinking water to the metropolis.

\section{REFERENCES}

[1] American Water Works Association (AWWA, 1971). Water quality and treatment, 3rd Edition. McGraw Hill Book Co, London.
[2] WHO/UNICEF. "Estimated Data from WHO/UNICEF Joint Monitoring Programme (JMP) for water supply and sanitation. Progress on Sanitation and Drinking Water, 2012 upgrade.

[3] J. L. Wu, H. A. Zeng, H. Yu, L. Ma, L. S. Xu, B. Q. Qin, "Water and sediment quality in lakes along the middle and lower beaches of the Yangtze river, China". Water Resources Management, 12, 3601-3618. 2012.

[4] W. U. Anake, N, U. Benson, A. A. Akinsiku, C. O. Ehi-Eromosele, and I. O. Adeniyi, "Assessment of trace metals in drinking water and groundwater sources in Ota, Nigeria". International Journal of Scientific and Research Publications (IJSRP), 4 (5), 1 - 4. 2014.

[5] C. G. Fraga, and P. I. Oteiza, "Iron toxicity and antioxidant nutrients". Toxicology, 180(1), 23-28. 2002.

[6] WHO (2004). Guidelines for drinking water quality, 3rd Edition.

[7] A. G. Abdulkadir, D. B Abdu, H.Ibrahim, and A. Abdullahi, "Assessment of heavy metals from the roots, barks and leaves of some selected medicinal plants (Moringa oleifera and Azadirachta indica) grown in Kashere metropolis". International Journal of Scientific Engineering and Applied Science (IJSEAS), 2 (11), 124 136. 2016.

[8] J. O. Nriagu, "A Silent epidemic of environmental metal poisoning". Environmental Pollution,50, 139-161. 1988.

[9] M. Soylak, F. A. Armagan, S. Saracoglu, L. Elci, M. Dogan, "Chemical analysis of drinking water samples from Yozgat, Turkey". Polish Journal of Environmental Studies, 2 (2), 151-156. 2002.

[10] S. O Adefemi, and E. E. Awokunmi, "Determination of physicochemical parameters and heavy metals in water samples from Itaogbolu Area of Ondo state, Nigeria". African Journal of Environmental Science and Technology 4 (3), 145-148. 2009.

[11] E. O. Longe, and M. R. Balogun, "Ground water quality assessment near a municipal landfill, Lagos, Nigeria". Research Journal of Applied Sciences, Engineering and Technology, 2 (1), 39-44. 2009.

[12] A. K. Singh, S. Bhagowati, T. K. Das, B. Yubbe, N. M. Rahman, P. Obing, W. S. K. Singh, C. Z. Renthlei, I. Pachuau," Assessment of heavy metals in drinking water of Northeastern India". Thakur Northeastern Regional Institute of water and land management, Tezpur 784027.

[13] I. Alfred, and E. A. Comport, "Portability of drinking water in an oil impacted community in southern Nigeria". Journal of Applied Science and Environmental Management, 135-141. 2005.

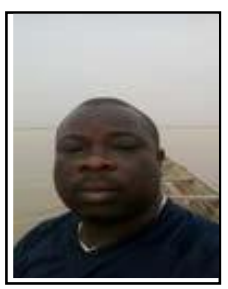

Abdulkadir A. G. is a lecturer at the Department of Chemical Sciences; Federal University Kashere. He received both his Bachelor of Science (Honours) Degree in Pure and Applied Chemistry and Master of Science Degree in Analytical Chemistry; from Bayero University, Kano, Kano State, Nigeria in the year 2000 and 2010 respectively. His area of interest lies in Analytical and Environmental Chemistry.

Ibrahim H. is a Senior lecturer at the School of Secondary Education (Science), Department of Chemistry; Federal College of Education (Tech.), Gusau, Zamfara State, Nigeria. He received both his Bachelor of Science (Honours) Degree in Pure and Applied Chemistry and Master of Science Degree in Organic Chemistry from Bayero University, Kano, Kano State, Nigeria in the year 2000 and 2010 respectively, and PhD Chemistry from University of KwaZulu Natal, Durban, KZN, South Africa in the year 2015. His specialty is in Organometallic Synthesis and Catalysis.

Kendeson A. C. is a lecturer at the Department of Chemical Sciences; Federal University Kashere, Gombe State, Nigeria. She received her Bachelor of Science (Honours) Degree in Pure Chemistry and Master of Science Degree in Applied Organic Chemistry from the University of Jos in the year 2004 and 2012 respectively. Her area of interest lies in Natural Products Chemistry

Yusuf A. is an undergraduate student at the Department of Chemical Sciences, Federal University Kashere, Gombe State, Nigeria 